\title{
AUNC
}

Zabytkoznawstwo i Konserwatorstwo XLIX

Toruń 2018

DOI: http://dx.doi.org/10.12775/AUNC_ZiK.2018.009

\section{Technologia i technika wykonania dziewiętnastowiecznych dekoracji teatralnych \\ na przykładzie obiektów ze zbiorów Fredrikshalds Teater w Halden - przyczynek do badań zbiorów}

\author{
ELŻBIETA SZMIT-NAUD \\ Zakład Konserwacji Malarstwa i Rzeźby Polichromowanej \\ Wydział Sztuk Pięknych, UMK w Toruniu \\ esn@umk.pl \\ ORCID: 0000-0002-5040-9723
}

Key words: Italian stage set, painting technique of the $19^{\text {th }}$-cent. scenery setting, Fredrikshalds Theatre

Słowa kluczowe: dekoracje teatralne sceny włoskiej, technika wykonania XIX w dekoracji teatralnych, teatr Fredrikshalds

\begin{abstract}
Technology and technique of the nineteenth century theater decorations by the example of the Fredrikshalds Teater in Halden. A contribution to the study of the collection.

The $19^{\text {th }}$-century painted scenery setting of the town theater in Halden (Norway) continue the tradition of an Italian stage sets. Collections of that kind are rare, especially in town theaters that have been exploited much more intensively than private ones. That is why the scenery sets preserved in Halden make an important part of heritage important not only for Norway culture, but also for European one. Their uniqueness - in comparison to several other European collections comprising $19^{\text {th }}$-century elements - is decided by the fact that there are not only fragments of particular stage sets surviving, but at least one compete scenery. The conducted re-
\end{abstract}


search on their technical structure, that in a broader context makes a component of the study on the $19^{\text {th }}$-century technique of making the painted theatre scenery sets, allow to better understand the elements of collection, including those designated for exhibition, actually subject to conservation treatment.

\begin{abstract}
Abstrakt
Malarskie dekoracje sceny teatru miejskiego w Halden, w Norwegii, powstałe w XIX w. są utrzymane w tradycji sceny włoskiej. Zbiory tego rodzaju należą do nielicznych, zwłaszcza w teatrach miejskich, intensywniej eksploatowanych niż prywatne. $Z$ tego względu zachowane malarskie scenerie z Halden stanowią dziedzictwo ważne nie tylko dla kultury Norwegii, ale także Europy. O ich wyjątkowości na tle kilku europejskich kolekcji zawierających XIX wieczne elementy decyduje fakt przetrwania nie tylko poszczególnych fragmentów scenerii, a kompletnej przynajmniej jednej wystawy. Wykonane badania ich budowy technicznej, które w szerszym kontekście stanowią komponent badań XIX wiecznej techniki wykonania malarskich dekoracji scenicznych, pozwalają lepiej poznać elementy kolekcji, w tym jej część przeznaczoną do ekspozycji, poddawaną aktualnie pracom konserwatorskim.
\end{abstract}

Przyczynkiem do podjęcia badań zbioru malarskich dekoracji scenicznych z Halden były poszukiwania o szerszym spektrum, dotyczące budowy i techniki wykonania iluzjonistycznych dekoracji teatralnych i obejmujące zachowane dziedzictwo tego rodzaju w Europie. Obok przykładów z teatrów dworskich francuskich, czeskich, niemieckich, scenerie z Halden stanowią rzadki przypadek dziewiętnastowiecznych zbiorów zachowanych w teatrze miejskim ${ }^{1}$, powstałych na potrzeby tego teatru i w zasadniczym zrębie istniejących do dziś.

\title{
Friedrikshalds Teater - historia i krótka charakterystyka zbiorów malarskich dekoracji sceny
}

Dziewiętnastowieczny teatr miejski Fredrikshalds Teater w Halden, niewielkim mieście w południowo-wschodniej Norwegii, jest najstarszym teatrem w tym kraju². Jako jedyna placówka z epoki na terenie złączonych ów-

1 Autorka przygotowuje publikację ujmującą przekrojowo technikę wykonania malarskich iluzjonistycznych dekoracji teatralnych od XVIII po początek XX w.

2 Starsza od niego jest XVIII-wieczna sala teatralna stowarzyszenia Konservativen, zwana Rosenlundsalen, również w Halden, obecnie nieużytkowana. 
cześnie unią Norwegii i Danii zachował w znacznym stopniu i oryginalną formę, i sceniczne wyposażenie ${ }^{3}$. Pozostałe teatry w tej części Skandynawii działające w ostatnich dziesięcioleciach XVIII i początku XIX wieku w Christianii (Oslo), Bergen, Drammen (w pobliżu Oslo), Helsingør, Røne, Trondheim, królewski teatr dworski w Christiansborg w Kopenhadze (jeszcze z lat 1766-1767) - nie przetrwały bądź zostały poważnie przebudowane i dawne oprawy ich scen nie zachowały się. Ocalały fragmenty starszych dekoracji scenicznych, najprawdopodobniej jeszcze z XVIII w., z rozebranego w połowie ubiegłego wieku miejskiego teatru w Arendal (1796), zasilając kolekcję w Halden, natomiast brak w Norwegii innych dziewiętnastowiecznych przykładów tego rodzaju obiektów poza pojedynczymi elementami (różnej proweniencji) przechowywanymi prawdopodobnie w teatrze w Drammen ${ }^{4}$. Fredrikshalds Teater jest rzadkością na europejską skalę, gdyż dziś wśród ocalałych scen mających jeszcze malarskie wyposażenie są głównie teatry dworskie.

Istniejący do dziś teatr miejski w Halden zbudowany został w 1838 roku według projektu Balthazara Nicolaya Garbena ${ }^{5}$. Konstrukcja jego sceny jest osadzona w tradycji „sceny włoskiej”, czyli wykorzystuje odpowiednio osadzone malarskie dekoracje dla uzyskania iluzyjnych przestrzennych scenerii. Prezentuje jej prostszy wariant, tj. z ograniczoną maszynerią podscenia i stosunkowo płytkim nadsceniem ${ }^{6}$, niemniej jednak pozwala na zmiany dekoracji, w które została stosownie wyposażona ${ }^{7}$. Zgodnie z pierwszym inwentarzem

3 Informacje historyczne dotyczące zbiorów z Halden za: Vidar Parmer, Fredrikshalds Teater 1838-1988 (Halden: Halden Historiske Samlinger, 1988), passim; Vidar Parmer, Teater, pantomime, linedans, ekvilibristikk, menasjeri, vokskabinett, kosmorama etc på Fredrikshald (Halden: Halden Komune, 1967), passim. Kwerendę na miejscu autorka przeprowadziła w 2010 oraz 2016 i 2017 r.

4 Według danych przekazanych przez Mille Stein z Norsk Institutt for Kulturminneforskning (NIKU) dekoracje w Drammen mogą pochodzić z lat 1870-1920 (w tym część malowana przez Jensa Wanga), niektóre należały do Teatru Narodowego w Oslo.

5 Istniejące wcześniej stowarzyszenia teatralne nie dysponowały przystosowanym budynkiem.

6 Fragmenty maszynerii w podsceniu, nieokreślone bliżej, usunięto podczas przebudowy teatru w 1930 r., prawdopodobnie nigdy nie służyły do wymiany kulis.

7 Podstawowe informacje dotyczące elementów „wystaw” sceny włoskiej, czyli tradycyjnej, zob. Elżbieta Szmit-Naud, „Iluzjonistyczne scenografie teatralne jako szczególny gatunek malarstwa dekoracyjnego. Technika wykonania na przykładzie dekoracji francuskich teatrów dworskich", Acta Universitatis Nicolai Copernici. Zabytkoznawstwo i Konserwatorstwo 38 (2010): 143-167. Typologia elementów tworzących malarskie dekoracje teatralne pełniej wyjaśniona w monografii: Elżbieta Szmit-Naud, Europejskie zbiory iluzjonistycznych scenerii teatralnych - dziedzictwo docenione? Perspektywa konserwacji zapobiegawczej (Toruń: Wydawnictwo UMK, 2018). 
pochodzącym z roku powstania teatru, na zbiór „wystaw” niezbędny do jego funkcjonowania składały się „Salon”, „Pokój mieszczański” z dwoma prospektami ${ }^{8}$ dekoracja „Lasu” i „Ulicy” oraz osobne elementy przedstawiające dwa drzewa, dwa tereny w formie krzaków z furtką, kryty strzechą „Dom wiejski” (zwany też „Chatą leśną”) będący dużą przystawką bądź fermem oraz elementy „praktykowane”: pojedyncze okno i troje drzwi do wstawiania w prospekt ${ }^{9}$. Autorstwo tych malarskich scenerii jest przypisywane Peterowi Frederikowi Wergmannowi, uznanemu duńskiemu malarzowi dekoratorowi, wcześniej aktywnemu w Christianii, a w owym czasie pracującemu dla teatru Halden. Powstałe w 1838 roku dekoracje z Halden zawierają też elementy wcześniejsze, na przykład części komponentów „Ulicy” są namalowane na odwrociu innych dekoracji, zgodnie z dosyć popularnym zwyczajem wtórnego wykorzystywania płócien.

Dekoracje przypisywane Wergmannowi stanowią zasadniczy zrąb kolekcji, choć w późniejszym czasie poddano je przeróbkom i przybyło kilka nowych, co należy wiązać z pracami Gustava i Ferdinanda Gjøsów w połowie XIX wieku, a później Rudolfa Kroga na przełomie stuleci. Sceneria „Salonu” (zwanego też „Czerwonym salonem”) została przemalowana. Po gruntownych przeróbkach, którym poddano także kulisy zestawu „Las”, ta wystawa zyskała inny wygląd i została spłycona. Później namalowany został do niej nowy prospekt oraz sufity, a przystawki w formie drzew uzyskały nowe korony. Zestawy przedstawiające trzy „Pokoje mieszczańskie” nie są kompletne i nie ma pewności, czyjego są autorstwa. Oprócz wspomnianej „Chaty leśnej” (Hut) jest jeszcze jedna, zwana „Winiarnią”, która ma „praktykowane” i okna, i drzwi; być może jej autorem jest Gustav Gjøs. Z nim bądź z jego bratem Ferdynandem prawdopodobnie należy także wiązać składającą się z sześciu kulis i prospektu (później przemalowanego) dekorację „Pokoju drewnianego”. Prospekt przedstawiający „Pejzaż” z górami w tle, wijącą się drogą i stawem został namalowany, jak się przypuszcza, również przez G. Gjøsa w 1848 roku $^{10}$. Kolejne elementy kolekcji, wyobrażające wnętrza, są późniejsze. Należy do nich „Salon rokokowy” z końca XIX wieku, zbudowany z trzech sufitów i jedenastu elementów na krosnach ustawianych w literę U, z których trzy zawierają praktykowane drzwi, a dwa - okna. Oprócz niego jest jeszcze inny

8 Termin „prospekt” oraz inne zapisane kursywą są elementami wchodzącymi w skład zestawu tworzącego teatralną wystawę.

9 Parmer, Fredrikshalds Teater, 19.

10 Parmer, Fredrikshalds Teater, 25. 
„Salon” z końca XIX wieku, znacznie przemalowany w następnym stuleciu. Kolejna dekoracja wnętrz mogła występować w trzech wariantach. Jej zasadnicze składowe na krosnach - części ścian - stanowią praktykowane drzwi oraz wypełnienia otworów, które umożliwiały zmianę charakteru wnętrz przez wstawienie różnego rodzaju panneaux - zielonych, innych imitujących tkaninę gobelinową lub różową tapetę. Ta wystawa została przemalowana w 1916 roku przez Rudolfa Kroga. Jest on autorem kolejnej dekoracji wnętrza - „Izby chłopskiej” z 1916 roku, wykonanej częściowo z wykorzystaniem płócien starszych dekoracji; jej ściany złożone są z par podwójnych krosien i prospektu. Krog sygnował ostatnie przemalowanie pochodzącej z 1838 roku kurtyny i prospektu „Lasu” oraz pomalował stałe elementy dekoracji sceny - portal prosceniowy i draperie za nim. Przypuszczalnie przemalował również wspomniany pejzażowy prospekt z górami w tle. Poza wymienionymi, zbiory Fredrikshalds Teater zawierają osobne elementy, powstałe od połowy XIX wieku do czasów po drugiej wojnie światowej. Obiekty te noszą ślady dawnych reperacji. Część z nich jest zapewne efektem zabiegów konserwatorskich wykonanych w latach osiemdziesiątych w Kopenhadze.

Z informacji zebranych przez Vidara Parmera wynika, że poszczególne wystawy mogły mieć różną głębokość, tj. składać się z trzech do pięciu par kulis i odpowiedniej liczby sufitów. Prawdopodobnie początkowo większość kulis była zwieszana, ale po przeróbkach sceny utrudniających ich użytkowanie zgodnie z wcześniejszym systemem nabito je na krosna. Szacuje się, że w Fredrikshalds Teater w Halden zgromadzono około 250 elementów dekoracji ${ }^{11}$. Inwentaryzacja zbiorów należących do Halden Historiske Samlinger (Kolekcje Historyczne Halden), oddziału Østfoldmuseene (Fundacji Muzealnej Østfold) nie jest jeszcze zakończona.

Iluzjonistyczne dekoracje repertuarowe nie są już używane na scenie ${ }^{12}$. Obecnie część zbioru jest przechowywana w magazynie zaaranżowanym we foyer teatru na poziomie podscenia, część mieści się jeszcze w nadsceniu, część przeniesiono do dawnego Domu Misyjnego zaadaptowanego do funkcji muzealnej i magazynowej. Na zbudowanej w nim scenie, po ukończeniu prac konserwatorskich ${ }^{13}$, ma być stale prezentowana wystawa złożona z kulis

11 Parmer, Fredrikshalds Teater, 20, 28.

12 Pełniejsze dane dotyczące teatru i kolekcji zob. Szmit-Naud, Europejskie zbiory; Parmer, Fredrikshalds Teater; Parmer, Teater, pantomime.

13 Prace prowadzone są od 2012 r. w ramach University of Oslo Summer School Conservation of Theater Sceneries, z przerwą w 2013 r., zob. Douwtje van der Meulen, „Monumental 
i sufitów „Lasu”, prospektu pejzażowego z górami w tle, fermu „Chata leśna” i (prawdopodobnie) dwóch lub jednego z wolno stojących drzew.

Przedstawiona krótka charakterystyka zbioru, dokonana na podstawie kwerendy, może ulec weryfikacji i uszczegółowieniu w toku dalszych badań, zarówno jego komponentów, jak i materiałów archiwalnych. Niemniej jednak już obecny stan wiedzy pozwala stwierdzić, że malarskie dekoracje z teatru miejskiego w Halden są wprawdzie w zasadniczym zrębie dziewiętnastowieczne, lecz obecna ich forma kształtowała się wieloetapowo. Podejmując badania tych obiektów wzięto pod uwagę utrudnienia i możliwości wynikające z tych uwarunkowań.

\section{Cel, założenia i metodyka badań}

Badania elementów dziewiętnastowiecznych dekoracji scenicznych teatru w Halden mieściły się w szerszym projekcie, obejmującym także fragmenty innych zbiorów z tej epoki, a służącym przybliżeniu techniki wykonania malarskich dekoracji scenicznych i jej ewolucji w dłuższej perspektywie czasowej. Zbiory w Halden wcześniej nie były poddawane tego rodzaju analizom. Intencją autorki było poszerzenie wiedzy o najstarszych elementach kolekcji, w tym rozpoznanie materiałów zastosowanych w toku ich tworzenia oraz etapów powstawania zachowanego układu warstw. Zgodnie z założeniem uzyskane wyniki mogą przynieść choćby częściową weryfikację dotychczasowych informacji na temat przekształceń, a także stanowić przyczynek do dalszych badań nad zbiorem.

Badania rozpoczęto od przeprowadzenia obserwacji in situ. Potem, po wytypowaniu kilku elementów zbioru, pobrano próbki umożliwiające m.in. określenie reprezentatywnych składników malarskiej palety oraz - w zakresie uwarunkowanym ilością materiału badawczego - spoiw i podobrazia. Do analizy zastosowano szereg metod fizykochemicznych. Po dokonaniu obserwacji mikroskopowych przeprowadzono badania składu pierwiastkowego metodą

Theatre Sceneries: Big Groups Big Problems?", w: Monumental Treasures Preservation and Conservation, XX NKF Congress, 21-23 October 2015, red. .Anna Rajainmoa, Marleena Vihakara, Satu Haapakoski, Stina Björklund, Erika Tiainen (Helsinki : The Nordic Association of Conservators, Finish Section, 2015), 228-235.W latach 2016, 2017 i 2018 prace konserwatorskie toczyły się z udziałem studentów Uniwersytetu Mikołaja Kopernika w Toruniu i autorki opracowania. 
rentgenowskiej analizy fluoroscencyjnej ${ }^{14}$. Następnie część próbek zbadano metodą spektroskopii w podczerwieni z transformacją Fouriera ${ }^{15}$, a z części wykonano przekroje i określono układ warstw. Wyniki obserwacji przekrojów uzupełniono w badaniach mikroskopowych UV/VIS ${ }^{16}$. Wybrane próbki poddano analizie metodą skaningowej mikroskopii elektronowej i mikroanalizy rentgenowskiej ${ }^{17}$. Po zakończeniu badań instrumentalnych przeprowadzono testy mikrochemiczne, uzupełniająco, w celu doprecyzowania wyników dotyczących spoiw i niektórych pigmentów niepozwalających na jednoznaczną interpretację $e^{18}$. W kilku przypadkach wykonano dodatkowo obrazowanie w tzw. technice fałszywych kolorów w bliskiej podczerwieni ${ }^{19}$.

14 Badania XRF wykonał w Zakładzie Technologii i Technik Malarskich Instytutu Zabytkoznawstwa i Konserwatorstwa UMK Adam Cupa posługując się kompaktowym energodyspersyjnym spektrometrem rentgeneowskim MiniPal 4025. Aparat został wyposażony w lampę rentgenowską z okienkiem bocznym o mocy 9W z katodą Rh (rodową). Układ lampy chłodzony jest powietrzem. Zakres napięcia lampy: od $4 \mathrm{kV}$ do $30 \mathrm{kV}$; zakres prądu: $1 \mu \mathrm{A}$ do $1 \mathrm{~mA}$. Zakres analityczny aparatu: od $\mathrm{Na}$ (sodu) do U (uranu).

15 Badania wykonali w Zakładzie Konserwacji Elementów i Detali Architektonicznych IZK UMK Wiesława Topolska i Michał Balewski. Widma absorpcyjne w podczerwieni rejestrowano za pomocą spektrometru fourierowskiego (FTIR) Alpha-P (Bruker Optics) przy wykorzystaniu techniki osłabionego całkowitego wewnętrznego odbicia (ATR - attenuated total reflectance), z pryzmatem diamentowym, metodą jednoodbiciową, rozdzielczość spektralna: $4 \mathrm{~cm}^{-1}$, akwizycja danych: 64 i 128 skanów. Próbki przeznaczone do badań miały postać proszku. Interpretacji wyników badań dokonał Paweł Szroeder w Instytucie Fizyki UMK wraz z autorką opracowania.

16 Badania w mikroskopii UV/VIS wykonały w Zakładzie Konserwacji Malarstwa i Rzeźby Polichromowanej IZK UMK Zuzanna Rozłucka i Magdalena Iwanicka. Przeprowadzono je z użyciem mikropskopu Nikon ECLIPSE E600 z zewnętrznym oświetlaczem halogenowym oraz z lampą rtęciową Nikon Super HB 1010 i standardowym blokiem filtrów UV. Stosowano powiększenie 100, 250 i $500 \mathrm{x}$.

17 Obrazowanie SEM przekrojów próbek wykonali Grzegorz Trykowski i Grażyna Szczepańska w Pracowni Analiz Instrumentalnych Wydziału Chemii UMK skaningowym mikroskopem elektronowym LEO 1430VP (LEO Electron Microscopy Ltd, Cambridge, England), z detektorem elektronów elastycznie odbitych (ang. backscattered electron - BSE), w trybie zmiennopróżniowym. Analizę EDS wykonano energodyspersyjnym spektrometrem rentgenowskim Quantax 200 (Bruker-AXS Microanalysis GmbH, Berlin, Germany), z detektorem EDX, XFlash 4010. Interpretację rezultatów badań SEM-EDS w zestawieniu z badaniami mikroskopowymi przekrojów próbek przeprowadziła autorka opracowania.

18 Badania wykonały autorka opracowania oraz Elżbieta Orłowska standardowymi metodami mikrochemicznymi.

19 Obrazowanie metodą „kolorowej podczerwieni” wykonał Adam Cupa w Zakładzie Technologii i Technik Malarskich IZK UMK przy użyciu mikroskopu Optiphot 2 i cyfrowego systemu rejestracji obrazu UV-VIS-NIR, zgodnie z metodą opracowaną pod kierunkiem Jarosława Rogóża. Próby interpretacji dokonano w konsultacji z J. Rogóżem na podstawie dotychczas opracowanych wzorców. 


\section{Elementy zbioru poddane badaniom i lokalizacja badanych stref}

Obserwacje in situ i badania przeprowadzono w dwóch etapach, uzależnionych od dostępu do elementów zbioru w zastanych warunkach ich przechowywania $^{20}$. W uzgodnieniu z opiekunem kolekcji badaniom wymagającym pobrania próbek zostały poddane wybrane obiekty: kulisa wystawy „Las” i ferm „Chata leśna” sięgające 1838 roku oraz kulisa „Salonu rokokowego” datowanego na koniec XIX wieku.

Zestaw tworzący scenerię „Lasu” początkowo składał się z pięciu par pojedynczych kulis, na których przedstawiony był bór świerkowy - tak prezentowała się dekoracja jeszcze w $1897 \mathrm{roku}^{21}$. W ramach przeróbek wykonanych przez Rudolfa Kroga w 1916 roku „Las” został przemalowany na liściasty, a pojedyncze kulisy połączone ze sobą i tworzą do dziś kulisy łamane (il. 1). Z dziesięciu sztuk powstało pięć i domalowana została jedna nowa - czyli powstały w sumie trzy pary. Badaniom poddano lewą kulisę pierwszego planu (obecne oznaczenie 001), zbudowaną z komponentów z 1838 roku, czyli reprezentatywną dla pozostałych podobnie skonstruowanych, mających zarówno pierwotne (w zakresie bliżej nieokreślonym), jak i widoczne wtórne opracowanie malarskie. Analizowano próbki z dwóch różnych stref zielonych i brązowej oraz włókna podobrazia w dolnej partii zewnętrznej kulisy.

Badania fermu „Chata leśna” oprócz tego, że budowały wiedzę o tym oddzielnym elemencie zbioru, były komplementarne w stosunku do badań kulisy „Lasu”, wnosząc dodatkowe informacje o palecie stosowanej w sceneriach malowanych w 1838 roku i umożliwiając ewentualne porównania struktury najwcześniejszych warstw malarskich, wykonanych prawdopodobnie przez P. Ch. Wergmanna. Pobrano łącznie siedem próbek warstw malarskich z różnych partii kolorystycznych (czerwieni, żółcieni, bieli, zieleni i czerni) i włókno płótna, poza strefami widocznymi jako poddane zabiegom (prawdopodobnie podczas wzmiankowanej restauracji w Danii w latach osiemdziesiątych XX wieku).

Hipotetyczne datowanie zestawu dekoracji „Salonu rokokowego” sytuuje jego powstanie w końcu XIX wieku, bez wskazania autorstwa. Rezultaty badania włókna podobrazia, warstw malarskich, białego tła i błękitnego detalu, zestawione z wynikami badań kulisy „Lasu” oraz fermu, stanowiły potencjalne źródło uzupełniających informacji odnośnie do okresu powstania malowidła.

${ }^{20}$ W 2010 r. podczas pierwszej kwerendy oraz uzupełniająco w 2016 i 2017 r. przy okazji przeprowadzania prac konserwatorskich przy elementach wystawy „Lasu”.

21 Parmer, Fredrikshalds Teater, 22. 


\section{Rezultaty przeprowadzonych badań}

W efekcie przeprowadzonych analiz i ich interpretacji ustalono stratygrafię i materiałowy skład elementów dekoracji w miejscach poddanych badaniom.

\section{Kulisa "Lasu”}

Kulisa łamana ze scenerii „Lasu”, złożona dwóch dawnych połączonych zawiasami, ma wysokość $345 \mathrm{~cm}$ (część wewnętrzna - od środka sceny) i $348 \mathrm{~cm}$ (część zewnętrzna) oraz szerokość odpowiednio 96,5-97,5 cm i $121 \mathrm{~cm}$. Listwy z drewna iglastego (przypuszczalnie sosnowego), z których zbudowane są krosna, mają szerokość 7,5 cm i grubość od 2,2 $\mathrm{cm}$ do $3 \mathrm{~cm}$ (listwa dolna jest grubsza), noszą ślady obróbki piłą tarczową. Połączone są ze sobą na zakładkę, pojedyncze odcinki mają długość od 96,5 do $122 \mathrm{~cm}$. Połączenia są wzmocnione, zapewne wtórnie, w toku przetwarzania kulis (w roku 1897 ? i 1916) wkrętami. Listwa pionowa krosna od strony sceny, cieńsza, tworzy zarazem sylwetę kulisy, która została wycięta piłą taśmową w szerszej desce; wzmocniono ją wtórnie dwiema grubszymi listwami, docinając profil wyrzynarką (il. 2). Oba krosna zespolone są stalowymi zawiasami w kulisę łamana - wtórnie, jak już wspomniano.

Podobrazie malowideł składa się z połączonych ze sobą kawałków płótna. Poddane badaniom włókna płótna z krosna zewnętrznego (od strony kulis) zidentyfikowano jako lniane. Podobrazie na krośnie zewnętrznym składa się z czterech, a na wewnętrznym - z pięciu kawałków, zszytych na okrętkę, z widocznymi późniejszymi poprawkami (na co wskazują różnie utlenione dwa typy nici). Płótno poszczególnych kawałków wydaje się identyczne, ma splot płócienny, nitki nierównej grubości, węzły, jest grube i rzadkie (gęstość na zewnętrznym krośnie kulisy 7 o. i 5-6 w. na1 $\mathrm{cm}^{2}$ ). Na krośnie wewnętrznym (z sylwetą) podobrazie złożone jest z pięciu zszytych kawałków innego, bardziej regularnego i gęstszego płótna $\left(12\right.$ o. i 9 w. na $\left.1 \mathrm{~cm}^{2}\right)$. Podobrazie jest przyklejone i przybite do listew krosien od strony lica za pomocą gwoździ. Połączenie (wtórne) obu krosien kulisy zamaskowano wąskim pasem płótna. Odwrocie obu kulis połączonych w kulisę łamaną nie nosi śladu wcześniejszego mocowania na nim papierowych osłon. Badaniami objęto zewnętrzną, dolną część kulisy (il. 3), gdzie, jak sądzono, obecność warstw najstarszych była bardzo prawdopodobna. Płótno zostało przeklejone najprawdopodobniej klejem glutynowym, z niewykluczonym dodatkiem skrobi. W badanych przekrojach próbek stwierdzono układ czterech do siedmiu warstw nałożonych na płótno. 
Struktura pierwszych z nich stała się czytelna dopiero po połączeniu obserwacji mikroskopowych obrazów kolejnych próbek uzyskanych w VIS, fluorescencji wzbudzonej UV, SEM wraz z detekcją EDS. Wyniki tych obserwacji umożliwiły wyodrębnienie warstw, a następnie, po dokonaniu porównań, ich najbardziej prawdopodobne chronologiczne przypisanie. $Z$ kolei rezultaty analiz SEM-EDX na przekrojach próbek wsparte obrazowaniem w tzw. technice fałszywych kolorów w IR i badaniami mikrochemicznymi na przekrojach oraz mikrochemiczną analizą pojedynczych pigmentów pozwoliły na ich identyfikację.

Obraz fluorescencji w UV uwydatnia przeklejenie pojedynczych włókien płótna widocznych w przekrojach próbek i zarazem zanurzenie ich w masie, która prawdopodobnie nie jest typową zaprawą, ale warstwą podmalowania (il. 4: 1a, b). Nie ma ona jednorodnego charakteru, są partie ciemnoszare i jasne, które nie tworzą jednoznacznie strefowego układu. Partie ciemniejsze mają szarobrązową barwę i zawierają przede wszystkim ziemne pigmenty żelazowe - ugier, brąz, czerwień, czerń (przypuszczalnie roślinną) oraz kredę z bardzo nieznaczną domieszką barytu (prawdopodobnie ze złoża). W jaśniejszych partiach, leżących na opisanej ciemniejszej warstwie lub w nią wmieszanych, zidentyfikowano oprócz wymienionych składników kredę i biel ołowianą jako dominujący komponent, często w większych aglomeratach, a lokalnie domieszki pigmentów ołowiowych: żółcieni, przypuszczalnie masykotu lub glejty oraz, w innych miejscach, minii i błękitu miedziowego. To zróżnicowanie składu jest też pośrednią wskazówką, że opisywane warstwy nie pełniły funkcji zaprawy, lecz raczej podmalowania.

Następna warstwa, którą zakwalifikowano już jako właściwą warstwę malarską, zależnie od miejsca pobrania próbki jest brązowoszara, czarna o ciepłym odcieniu lub ciemnoszara o chłodnym błękitnawym bądź zielonkawym odcieniu. Warstwę tę stanowi mieszanina czerni (najprawdopodobniej drzewnej), kredy, czerwieni żelazowej, lokalnie z domieszką minii lub glejty i bieli ołowiowanej, a w wersji chłodnej głównie czerni i drobnych cząstek czerwieni żelazowej oraz lokalnie: w partii brązowej - z domieszką błękitu miedziowego, a w partii ciemnozielonej - zieleni z grupy arseninów miedzi (będącej zielenią Scheleego lub szwajnfurcką) ${ }^{22} \mathrm{z}$ dodatkiem ugru i domiesz-

22 Nicholas Eastaugh et al., Pigment Compendium. A Dictionary and Optical Microscopy of Historical Pigments (Amsterdam: Elsevier, Butterworth-Heinemann, 2008), 127, 128, 342. Zieleń Schellego, występująca w różnych odmianach i pod różnymi nazwami, w malarstwie dekoracyjnym wciąż obecna w XIX w., to pigmenty będące mieszaninami arseninów i arsenianów miedzi; zieleń szwajnfurcka (znana też pod innymi nazwami, m.in. jako szmaragdowa), wy- 
ką żółcieni chromowej (chromian baru i cynku). Zieleń i żółcień skupione są przede wszystkim w górnej strefie, lecz bez wyraźnego rozgraniczenia odrębnej warstwy (il. 4: 2). Opisany dotąd układ charakteryzuje widoczna na skanie SEM-EDS większa i bardziej jednorodna zawartość wapnia w porównaniu z następnymi warstwami (il. 4 c). Opisane obserwacje pozwalają wnioskować, że jest to pozostałość pierwszego opracowania malarskiego, przedstawiającego bór iglasty. Skład warstw odpowiada domniemanej ciemnej i chłodnej kolorystyce, jaka powinna charakteryzować tego typu przedstawienie. Najprawdopodobniej górną, bardziej barwną partię opracowania częściowo zmyto, by uzyskać pozbawione detali tło nowego przedstawienia.

Wyżej, w badanej strefie ciemnej zieleni, fragmenty jasnej warstwy zielonożółtej są zanurzone w warstwie poprzedniej, co świadczy o malowaniu mokre w mokre, pojedynczymi pociągnięciami pędzla. Te żółtozielone fragmenty zawierająj żółcień będącą mieszaniną chromianów, ołowiu i prawdopodobnie także baru i cynku z dodatkiem błękitu pruskiego oraz niewielką ilością kredy z domieszką gipsu. W innych partiach opisane warstwy pokrywa - wlewając się miejscowo w ubytki - mieszanina błękitów pruskiego i ultramaryny z minią i pigmentami żelazowymi - czerwienią lub brązem. Ta warstwa buduje niebieskie cienie w kompozycji przedstawiającej las liściasty (il. 1; 3; 4 a, b: - warstwa 3). W partii brązu mieszaninę błękitów zmieszanych z czerwieniami stanowią błękit pruski i miedziowy. Wierzchnie, ostatnie warstwy w badanych partiach zieleni są zróżnicowane. Ciemnozielona, chłodna warstwa została namalowana zielenią, która prezentuje się jednorodnie na przekroju, lecz jest mieszaniną żółcieni chromianowych (chromianów cynku, ołowiu i baru) z niewielką ilością kredy z domieszką gipsu i błękitu pruskiego. Jasnozielone liście namalowano farbą o podobnym składzie, ale z dominującym udziałem wymienionych żółcieni i nie jest wykluczony dodatek jakiejś zieleni organicznej osadzonej na siarczanie baru. Warstwa malarska miesza się lokalnie ze spodnią (il. $4 \mathrm{c}$ - warstwa 4). Warstwę wykończeniową w tej partii stanowi jaskrawa jasna żółcień złożona z wymienionej wyżej mieszaniny chromianów z dodatkiem kredy i barytu (il. 4 c). Ze względu na bardzo ograniczoną ilość materiału badawczego nie było możliwe precyzyjne określenie substancji błonotwórczej. Przeprowadzone analizy wskazują na spoiwo skrobiowo-białkowe.

naleziona w toku prób polepszenia zieleni Scheelego, to octoarsenin miedzi (II) (metaarsenianooctan miedzi). Lokalizacja pierwiastków As i $\mathrm{Cu}$ na skanie wskazuje na niewątpliwą obecność pigmentu z tej grupy. 
Obserwacje powierzchni malowidła, wygląd warstw na przekrojach i analiza ich składu, ustalenie, że określone efekty barwne w ostatnich warstwach uzyskano z mieszanin innych składników niż użyte w warstwach spodnich - pozwalają uznać, że warstwy pokrywające badane fragmenty kulisy „Lasu” powstały w toku powstawania obecnie widocznej dekoracji przedstawiającej las liściasty i nanoszone były „mokre w mokre”.

\section{Fragment wystawy „Salon rokokowy”}

Zbudowane na krosnach elementy dekoracji „Salonu rokokowego”, zestawiane razem, tworzą dekorację wnętrza typu pudełkowego, który w XIX wieku zastąpił wnętrza dotąd budowane kulisowo. Zestaw zawiera kulisy z praktykowanymi drzwiami i oknem (il. 5). Krosna zbudowane są podobnie jak wcześniej opisane; płótno podobrazia, również o splocie płóciennym, zidentyfikowane jako najprawdopodobniej lniane, znacznie gęstsze (19 o., 16 w. na $1 \mathrm{~cm}^{2}$ ), zostało przeklejone, co wyraźnie uwidacznia wygląd włókien w przekroju warstw.

W partii tła, z którego pobrano próbkę, fragmenty włókien płótna otacza warstwa ugrowobrązowa, zawierająca ugier i brąz żelazowy oraz czerń roślinną, kredę i dodatek barytu (il. 6: 1). Tworzy ona - w przeciwieństwie do przypadków opisanych podczas analizy warstw w próbkach z kulisy „Lasu” - ciągłą strukturę i można ją uznać za warstwę zaprawy. Na niej leży cienka warstwa intensywnie żółta, złożona z mieszaniny żółcieni ołowiowych, głównie tlenku (masykot lub glejta) oraz chromianu, kredy, z nieznaczną domieszką ugru (il. 6: 2). Powyżej znajduje się gruba biała warstwa, którą stanowi głównie kreda i bardzo niewielka domieszka czerni roślinnej i ugru. Przykrywa ją, nie tworząc wyraźnej granicy, kolejna biała warstwa, zawierająca przede wszystkim kredę z domieszką barytu i bielą cynkową oraz nieznaczny dodatek żółcieni ołowianej i ugru (il. $6: 3$ i 4). Generalnie całą stratygrafię charakteryzuje jednorodna obecność kredy naturalnego pochodzenia (il. 6 c), z domieszką barytu, co wskazuje, że stanowiła ona zasadniczy składnik białej farby używanej w procesie malowania. Spoiwo warstw malarskich ma charakter skrobiowo-białkowy.

W drugiej próbce z tego samego elementu dekoracji „Salon rokokowy” między włóknami płótna widoczne są pozostałości zaprawy, a bezpośrednio na płótnie leży warstwa wtórna, złożona z bieli tytanowej i cynkowej oraz kredy z błękitem (nieokreślonym, przypuszczalnie współczesnym organicznym) i domieszką czerwieni żelazowej. W spoiwie tych warstw występują 
substancje białkowe (najprawdopodobniej klej glutynowy). Układ i cechy warstwy malarskiej wskazują, że jest wtórna, pochodzi przypuszczalnie z czasu renowacji. Niebieski cień na krawędzi drzwi również jest przemalowaniem, zawiera głównie biel tytanową z kredą i współczesny błękit (prawdopodobnie organiczny - ftalocyjaninowy?). Zarówno zidentyfikowane składniki oryginalnych warstw malarskich „Salonu rokokowego” jak i porównanie wyglądu warstw malarskich na przekrojach potwierdzają, że mają one inny charakter niż pierwsze warstwy z kulisy „Lasu”, co stanowić może argument na rzecz różnego czasu powstania tych dekoracji.

\section{Ferm „Chata leśna”}

Ferm „Chata leśna” ma wysokość 2,8 m przy szerokości 2,15 m (il. 7). Jego konstrukcję stanowią krosna $\mathrm{z}$ dodatkowymi pionowymi listwami umożliwiającymi zamocowanie „praktykowanych” (otwieranych) drzwi. Listwy krosna mają od 5 do $7 \mathrm{~cm}$ szerokości, sylweta fragmentu dachu wycięta jest z grubej tektury, przybitej gwoździami. Płótno użytejako podobrazie jest płótnem konopnym o nitkach zróżnicowanej grubości i splocie płóciennym, rzadkim i dość regularnym (11 o. i 9 w. na $\mathrm{cm}^{2}$ ). Zszyte zostało z trzech ułożonych pionowo kawałków i osobnego kawałka pokrywającego ramę drzwi. Obecnie jest wtórnie zamontowane na krośnie ${ }^{23}$, pierwotnie było zamocowane od lica i częściowo na bocznej krawędzi listew za pomocą gwoździ.

Fluorescencja włókien płótna widocznych w przekrojach próbek wskazuje na jego przeklejenie. Włókna otoczone są warstwami o zróżnicowanej barwie, zależnie od partii malowidła, co sugeruje, podobnie jak w opisanej kulisie „Lasu”, że warstwy te należy uznać za rodzaj podmalowania wykonanego bezpośrednio na płótnie. Pierwsza warstwa leżąca na płótnie jest szarobrązowa - w partii strzechy i dachówek oraz w strefie zacienionej ściany $\mathrm{z}$ roślinnością z prawej strony, rudawa - w ugrowym daszku nad drzwiami, brązowoszara i jasnoszara - w partii ściany z listowiem, szara o ciepłym odcieniu - na jasnym fragmencie nad oknem (il. 8; 9; 10: 1). W szarobrązowym podmalowaniu zidentyfikowano następujące składniki: kredę naturalną (czasem z domieszką gipsu), biel ołowianą, ziemne pigmenty żelazowe (żółte i brązowe ugry i czerwienie), cząstki czerni, przypuszczalnie kostnej. W partii

23 Po konserwacji wykonanej w Danii, prawdopodobnie w 1986 r., której poddano też inne elementy zbioru z Halden. Na podstawie raportu udostępnionego przez NIKU: Jon Brænne, „Rapport Kunst og inventar nr 22/2005, Halden Teater Kulissesamlingen” (Raport fra befaringen den 6.6.2005, 2, NIKU, Oslo). 
dachówek podmalowanie to zawiera ciemną czerwień żelazową w większych aglomeratach, z towarzyszącą jej domieszką barytu (il. 8 c). W warstwach jasnoszarych występują te same składniki, lecz w innych proporcjach. W podmalowaniu rudawym dominują pigmenty żelazowe z domieszką żółcieni ołowiowej (prawdopodobnie glejty). Pierwsza właściwa barwna warstwa malarska jest w badanych strefach cienka, z wyjątkiem jasnej partii ściany (biel nad oknem), gdzie ma znaczną grubość i zawiera, oprócz kredy, głównie biel ołowianą i drobnoziarniste pigmenty żelazowe o żółtym i brązowym odcieniu, dodatek glejty i nieliczne cząstki czerni. W partiach czerwonych i żółtych jest to warstwa brązowa, w strefie dachówek i strzechy - o czerwonawym odcieniu, i składają się na nią głównie czerwienie żelazowe (te same, które występują w warstwie podmalowania, ale o drobniejszej frakcji) oraz kreda $\mathrm{z}$ dodatkiem bieli ołowianej i czerni. W partiach zieleni (kępki traw, liście) warstwa malarska ma barwę szarozieloną i zawiera - w różnych proporcjach, zależnie od waloru - biel ołowianą z kredą z dodatkiem zieleni z grupy arseninów miedzi oraz pigmentów żelazowych i czerni (il. 8-10: 2). Pokrywa ją warstwa wykańczająca, o intensywniejszej barwie, złożona z tej samej zieleni z dodatkiem żółcieni chromowej i siarczanu baru oraz domieszki pigmentów żelazowych (ugru żółtego i brązowego) oraz czerni ${ }^{24}$ (il. 10: 3). Wykańczające warstwy malarskie zawierają w partiach żółtych (strzechy, daszku) ugier w mieszaninie z kredą i jaskrawą ciemną żółcienią ołowiową, w odcieniu glejty, w partii czerwonych dachówek - minię z bielą ołowianą i nieznaczną domieszką kredy i czerwieni żelazowej (il. 8: 3). Biały fragment ściany nad oknem w miejscu poddanym badaniom pokryty jest jeszcze dwiema warstwami (il. 9: 3, 4). Pierwsza, nieznacznie ciemniejsza od poprzedniej, ma zbliżony do niej skład, ale biel ołowiowa występuje w niej tylko w domieszce, natomiast zawiera więcej drobnoziarnistej czerni. Ostatnia warstwa zawiera te same składniki z przewagą kredy. Czerń występująca w opisanych warstwach malarskich to prawdopodobnie czerń kostna, na co wskazuje identyfikacja próbki pochodzącej z czarnej warstwy malarskiej na drzwiach. Spoiwo farb, którymi namalowano „Chatę leśną”, jest najprawdopodobniej skrobiowe ${ }^{25}$.

24 Analiza SEM-EDS wskazuje na występowanie żółcieni chromowej w odmianie będącej mieszaniną chromianu i siarczanu ołowiu. „Chrome yellow”, CAMEO Materials Database (dostęp February 2, 2018), http://cameo.mfa.org/wiki/Chrome_yellow. Brąz jest najprawdopodobniej „brązowym ugrem” (goetyt) - Eastaugh et al., Pigment Compendium, 176,177. Nie stwierdzono obecności manganu w badanych próbkach, co nie pozwala go uznać za umbrę.

25 Na podstawie analizy FTIR pobranych próbek warstw malarskich. Zawartość substancji błonotwórczych w warstwach malarskich dekoracji teatralnych stanowi zaledwie ok. 3\% suchej 


\section{Wnioski i perspektywy dalszych badań}

Przeprowadzone badania wybranych elementów dekoracji teatralnych ze zbioru w Halden pozwoliły poznać charakterystyczne cechy i skład budujących je warstw malarskich i zarazem dokonać porównań, które prowadzą do kilku spostrzeżeń. Wygląd na przekrojach próbek w VIS i na obrazie SEM warstwy szarobrązowego podmalowania fermu „Chata leśna” przypomina fragmenty podmalowania o podobnej barwie w analizowanych próbkach $k u$ lisy „Lasu”. Zastosowanie tej samej zasady, podobnych mieszanin pigmentów, których rozdrobnienie (widoczne w przekrojach) także wydaje się podobne, może nasuwać przypuszczenie, że dekoracje zostały wykonane w zbliżonym czasie lub przez tego samego malarza - hipotetycznie Wergmanna. Warstwy malarskie przynależne do pierwszej kompozycji w kulisie „Lasu” obecnie mają mniejszą grubość, a ich (tzn. warstw pierwotnych) układ nie jest kompletny, najprawdopodobniej wskutek starcia w celu ujednolicenia tła dla nowej kompozycji. Rodzaj płótna użytego jako podobrazie kulisy „Lasu” i fermu nie jest identyczny (w kulisie „Lasu” najprawdopodobniej lniane, w fermie „Chata” konopne), lecz ferm jako dodatkowy element wzbogacający scenerie mógł zostać wykonany oddzielnie, na przykład na płótnie odzyskanym z innych dekoracji ${ }^{26}$. Przeprowadzone analizy i dokonane spostrzeżenia dają podstawy do podjęcia próby określenia zestawu pigmentów i wypełniaczy stosowanych w najwcześniejszym okresie powstawania malowideł scenicznych Friedrikshalds. Na ów zestaw składa się kreda (naturalnego pochodzenia) stosowana jako biel, z możliwą domieszką barytu, biel ołowiowa, żelazowe pigmenty ziemne w odcieniu ugrów żółtych, brązowych i czerwieni, żółcień ołowiana w odcieniu glejty, żółcień chromowa będąca głównie chromianem ołowiu, minia, zieleń z grupy arseninów miedzi (Scheelego bądź szwajnfurcka, zwana też szmaragdową), błękit miedziowy (przypuszczalnie bremeński), czerń (przypuszczalnie roślinna oraz kostna).

W świetle dostępnych informacji jedno z wolno stojących drzew uzupełniających scenerię leśną ma jeszcze płótno z 1838 roku i prawdopodobnie pierwsze warstwy na nim są współczesne tym, które tworzyły widok iglastego

masy, co stanowi istotne ograniczenie możliwości identyfikacji, a wobec znikomej ilości materiału badawczego, jaką dysponowano, nie pozwala zastosować innych, selektywnych metod identyfikacji (np. GC-MS).

${ }^{26}$ Jak inne scenerie przypisywane Wergmannowi, namalowane z wykorzystaniem płócien starych dekoracji, które przywiózł ze sobą z Christianii. 
lasu na kulisach ${ }^{27}$. Poddanie ich badaniom i porównanie wyników z uzyskanymi dla omówionych tu kulisy „Lasu” oraz fermu potencjalnie pozwoliłoby uzupełnić zdobyte informacje o najstarszych elementach kolekcji.

Zestaw pigmentów zidentyfikowany w badanym fragmencie tła kulisy „Salonu rokokowego” jest z oczywistych względów bardziej ograniczony i nie można na jego podstawie określić całej palety, niemniej jednak możliwe jest dokonanie porównań pozwalających na rozróżnienia między składnikami zastosowanymi w tej partii oraz opisanymi poprzednio, a także tymi, które stanowią najpóźniejsze warstwy w kulisie „Lasu”. Kreda użyta jako biel zawiera regularną domieszkę siarczanu baru, ugry są w postaci bardziej rozdrobnionej, podobnie żółcień ołowiowa (glejta), a chromian ołowiu występuje w odmianie o intensywniejszej barwie.

Warstwy malarskie, które tworzą obecną dekorację kulisy „Lasu”, przedstawiającą las liściasty, różnią się składem od wcześniej opisanych - paleta mimo podobieństw wykazuje różnice. Kreda stanowi w nich mniejszy dodatek $^{28}$, w większej proporcji natomiast występuje biel barytowa. Użytą żółcienią, w odróżnieniu od poprzednio stosowanych, jest mieszanina chromianów baru, cynku i ołowiu, w której zdaje się przeważać chromian baru. Czerwienią jest czerwień żelazowa o oranżowym odcieniu (drobnoziarnista, lecz zaglomerowana). Wykorzystano jednocześnie kilka błękitów - pruski, ultramarynę i domieszkę błękitu miedziowego. Zieleń jako osobny pigment w badanych strefach nie występuje, posłużono się bardzo dobrze rozdrobnioną, jednorodną mieszaniną żółcieni z błękitem pruskim - być może gotową mieszanką z gatunku tzw. zielonych cynobrów ${ }^{29}$. W toku obserwacji warstw malarskich in situ i na przekrojach uczytelniła się charakterystyczna cecha dotycząca

27 Parmer, Friedrikhalds Teater, 23.

28 Można przypuszczać, porównując rozkład wapnia na przekrojach, że wcześniejsze opracowanie, wykonane $\mathrm{w}$ innej tonacji, było także $\mathrm{z}$ tego powodu mniej intensywne barwnie od obecnego.

29 Badania omawianego fragmentu kulisy 001 „Lasu” wykonane w 2010 r. i powtórzone w $2017 \mathrm{r}$. nie potwierdzają informacji zawartej w raporcie z badań wykonanych w $2013 \mathrm{r}$. w Oslo dla kulis 003 i 004, sugerujących obecność zieleni „szmaragdowej” (miedziowo-arsenowej) także w wierzchniej warstwie malarskiej: Douwtje van der Meulen, „Mapping the Presence of Arsenic, Cooper and Lead on Wings and Backdrop of Theatre Scenery 'The woods'. Fredrikshalds Theatre" (IP project: 2013-1-NO1_ERA10-06367, Oslo 2013, University of Oslo), 19-21. Badane były próbki głównie z kulis 003 i 004 oraz kilka próbek z prospektu z widokiem górskim, zestawianego w ocenie ze scenerią leśną. Rezultaty zostały omówione w sposób ogólny. Definitywne rozstrzygnięcie, czy pigment ten był stosowany w wierzchnich warstwach, czyli w przedstawieniu wyobrażającym las liściasty, wymagałoby, oprócz porównań już wykonanych przekrojów, dalszych badań na próbkach pobranych z innych stref. 
warsztatu. Z jednej strony jednoczesne stosowanie kilku niebieskich pigmentów, z drugiej zaś występowanie aglomeratów źle zdyspergowanych czerwieni żelazowej oraz błękitów w niebieskofioletowych cieniach wskazuje na mieszanie tych pigmentów ze spoiwem bezpośrednio na palecie, być może w myśl zasady opisywanej przez Georges'a Moyneta ${ }^{30}$. Warstwy malarskie fermu „Chata leśna” i spodnie warstwy kulisy „Lasu” nie zdradzają takiej praktyki - sprawiają wrażenie wykonanych zgodnie z wcześniejszym kanonem techniki malarskiej stosowanej w iluzjonistycznym malarstwie scenicznym ${ }^{31}$, jakim było korzystanie z farb złożonych z pigmentów uprzednio zdyspergowanych w spoiwie, mieszanych na palecie już w tak przygotowanej postaci ${ }^{32}$. Widoczne mieszanie wielu pigmentów z tej samej tonacji barwnej - tu błękitów - i mokrych jeszcze warstw ze sobą (il. 4) w trakcie malowania wskazuje na odstępstwo od zasad obowiązujących w teatralnym malarstwie dekoracyjnym posługującym się techniką klejową i traktowanie procesu malowania z większą swobodą, przywodzącą na myśl malarstwo sztalugowe alla prima.

Czy są to cechy charakterystyczne warsztatu malarza-dekoratora będącego autorem aktualnej scenerii „Lasu”, czyli Rudolfa Kroga - pozostaje do rozstrzygnięcia. Podjęcie badań elementów, w których bez wątpienia warstwy malarskie obecnego przedstawienia są warstwami pierwotnymi, stanowiłoby zasadniczy krok w tym kierunku, gdyż pozwoliłoby na zdobycie komplementarnych informacji odnośnie do zastosowanych środków i techniki malarskiej. Do takich elementów należą: ostatnia kulisa (nr 006), całkowicie „nowa” w stosunku do poprzednio funkcjonujących, złożonych w kulisy łamane i przemalowanych, oraz sufity namalowane od podstaw przez Rudolfa $\mathrm{Kroga}^{33}$. Dookreślenie charakterystycznych cech warstw malarskich jego autorstwa pozwoliłoby także precyzyjniej rozpoznać obszar interwencji Kroga na prospekcie z widokiem górskim, wtórnie zestawionym z leśną scenerią.

30 Georges Moynet, Trucs et décors. Explication raisonnée de tous les moyens employés pour produire les illusions théâtrales (Paris: Librairie illustrée, 1893), 378.

31 Stosowanym także przez późniejszych malarzy dekoratorów, nawet w XX w., zob. Gustave Coquiot, Nouveau manuel complet de peintre décorateur de théâtre (Paris: Mulo, 1927 - faksymile z 1980 r.), 119; Xavièr de Courville, Décors de théâtre: invention, construction, peinture, conseils d'un artisan aux amateurs (Paris: Editions Bourrelier, 1949), 54, 56; Vladimir Polunin, The Continental Method of Scene Painting (London: Dance Books, 1980 - I wyd. 1927), 24, 25.

32 Joseph-Antoine Pérnety, Dictionnaire portatif de peinture, sculpture et gravure avec un traité pratique des différentes manières de peindre (Paris: Bauche, 1757), XXVII (dostęp february 10, 2018), https://archive.org/details/dictionnaireport00pern; de Courville, Décors de théâtre, 54 .

33 V. Parmer, Fredrikshalds Teater, 22. 
Badanie budowy i techniki wykonania zachowanych zabytkowych malarskich dekoracji teatralnych - zwłaszcza wiele lat używanych - jest zadaniem trudnym, choć zarazem fascynującym. Interpretacja często nieoczywistych wyników wymaga pogłębionej analizy, uwzględniającej trwałą odwracalność stosowanej techniki malarskiej i czasem skomplikowaną historię materialną tych malowideł. Przedstawione dotychczasowe badania elementów teatralnych wystaw z Halden dały wgląd w niewielki, lecz istotny fragment zbiorów. Stanowiąc przyczynek do eksploracji szerzej zakrojonych, umożliwią między innymi pełniejsze przedstawienie wystawy, która w zamierzeniu Muzeum będzie w sposób stały eksponowana, by reprezentować malarskie scenerie teatralne zachowane w Halden.

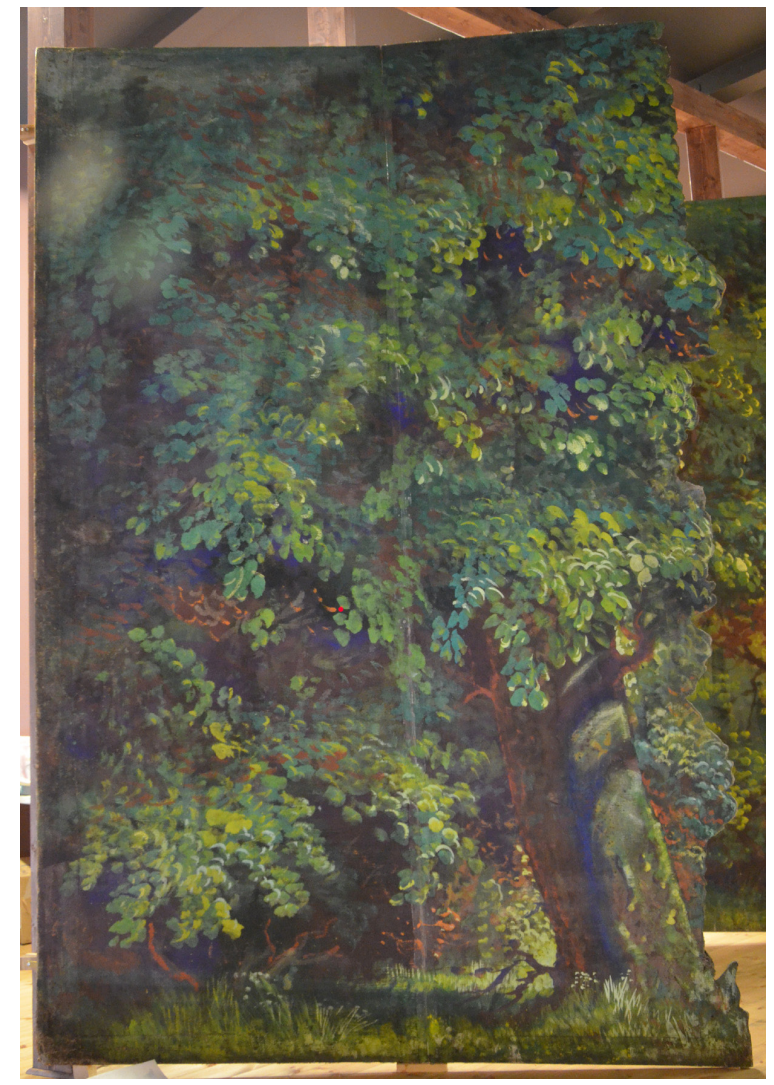

il. 1. Kulisa łamana wystawy Las, (001) w formie aktualnej (po przekształceniach z 1916 r.). Fot. P. Śwituszak 


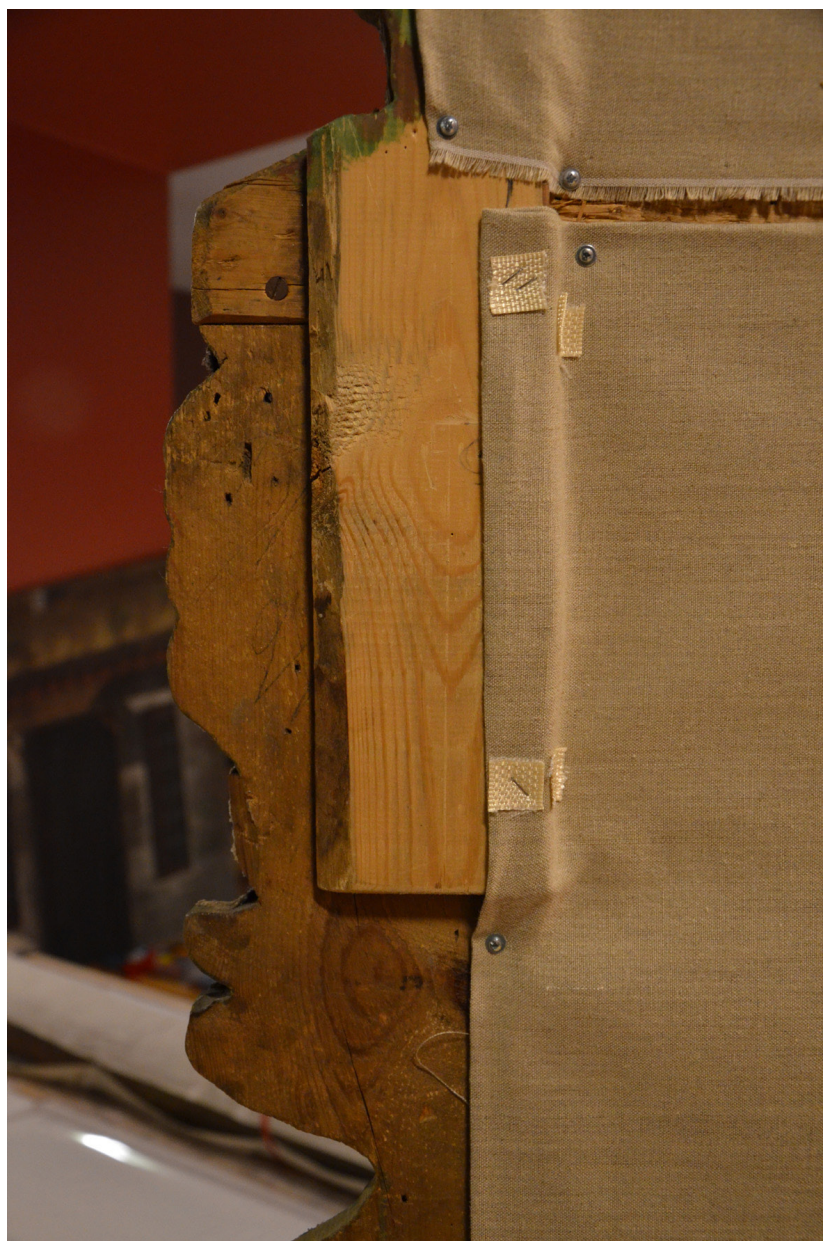

il. 2. Fragment kulisy 001, detal budowy - wtórne wzmocnienie sylwety (osłona $\mathrm{z}$ prawej strony dodana $\mathrm{w}$ trakcie prac konserwatorskich w 2014 r.). Fot. E. Szmit-Naud 


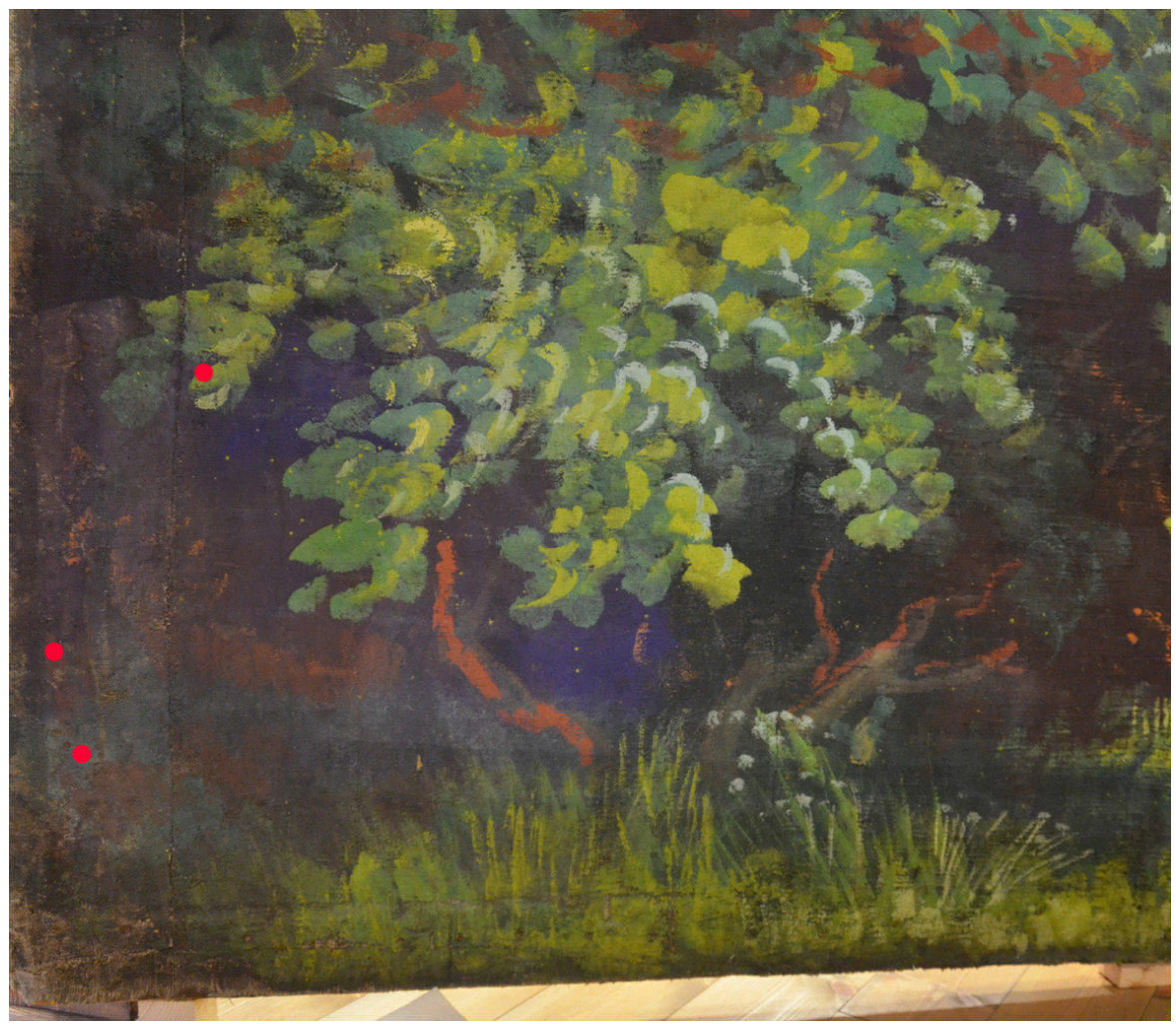

il. 3. Fragment kulisy 001, miejsca poddane badaniom - z partii zieleni ciemnej, brązu, jasnej zieleni-żółcieni. Fot. E. Szmit-Naud 


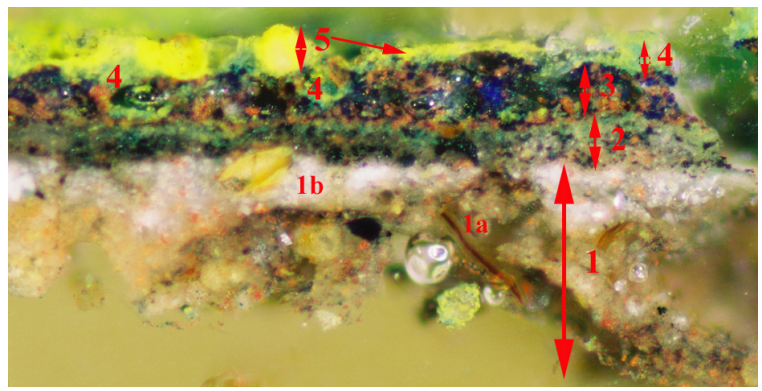

a)

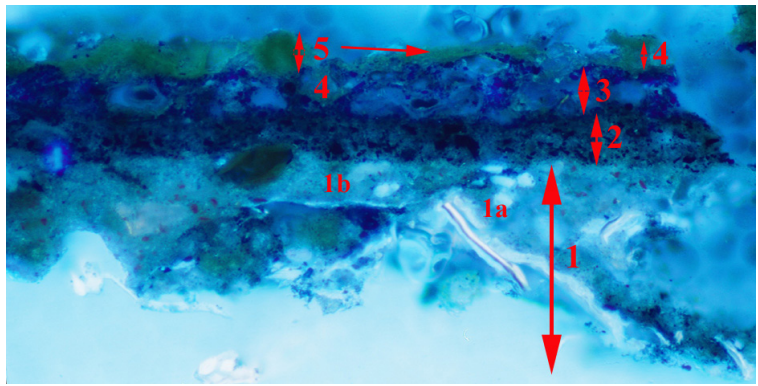

b)

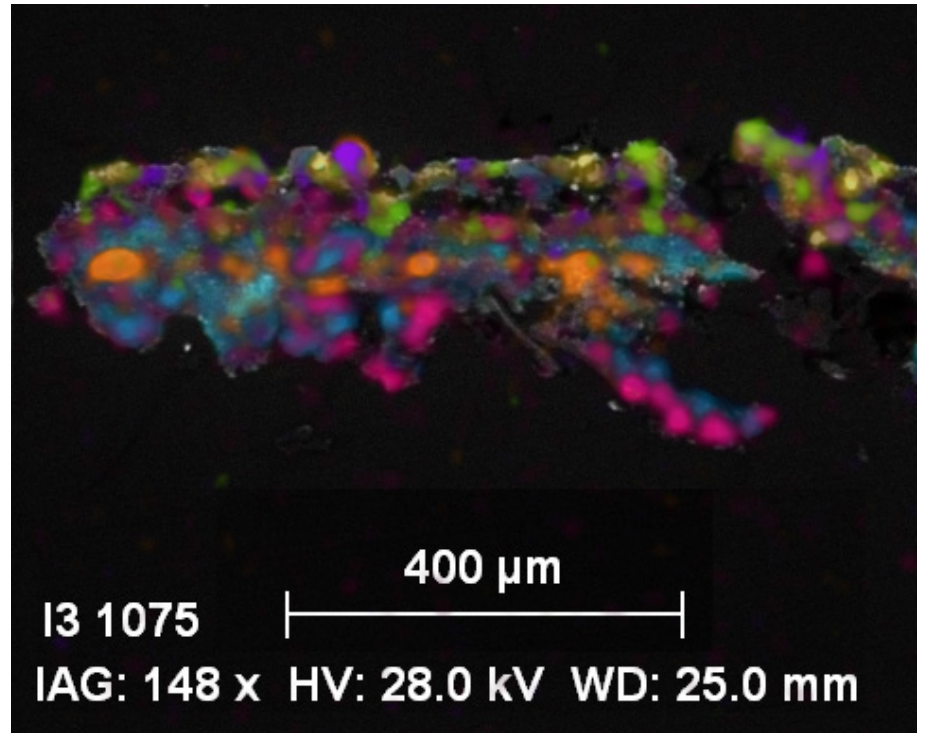

c)

il. 4. Przekrój z warstwy jasnozielono- żółtej na liściu w kulisie 001 Lasu, a) VIS, b) UV, c) SEM-EDS. Na skanie SEM-EDS zaznaczono: Zn (zielony), Cr (fiolet), Ba (żółty) Fe(ciemny róż), $\mathrm{Pb} / \mathrm{As}$ (oranż), Si ( błękit), Ca (cieplejszy błękit). Skład warstw 5 i 4 w lokalnej analizie SEM-EDS: Ca, S, Si, Ba, Pb, Cr, Zn, Fe, Al, skład warstwy 3: Ca, Si, Al, S, Ba, Pb, Cu, As, Cr, Cl, P. Fot. VIS W. Grzesik, UV-. Z. Rozłucka,; oprac. skanu SEM-EDS - E Szmit-Naud 


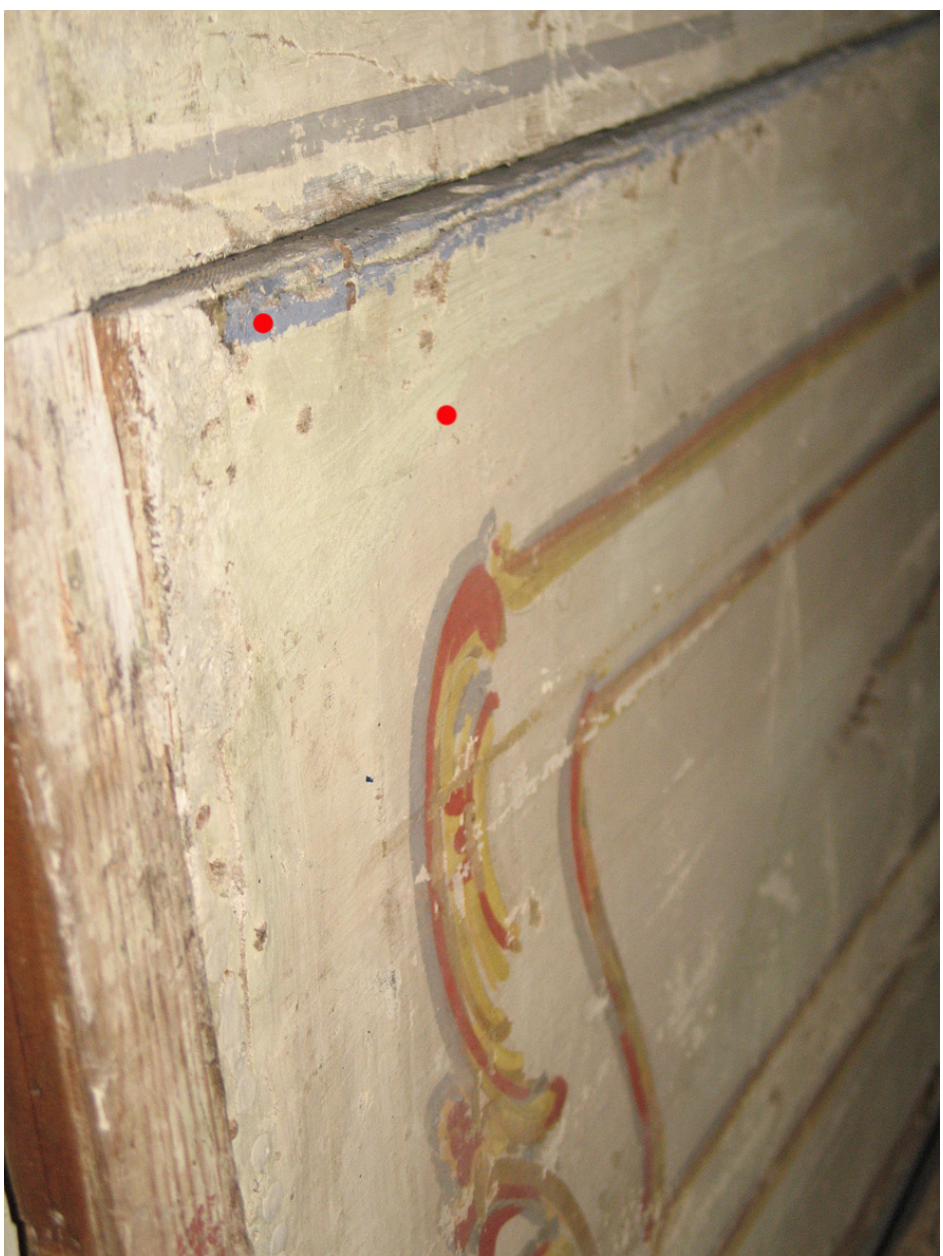

il. 5. Fragment kulisy wystawy Salon Rokokowy, z k. XIX w; miejsca poddana badaniom- białe tło, niebieski cień. Fot. E. Szmit-Naud 


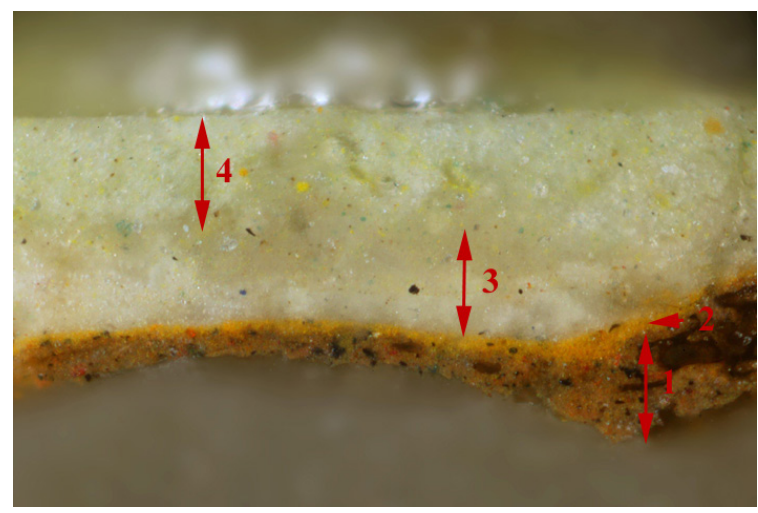

a)

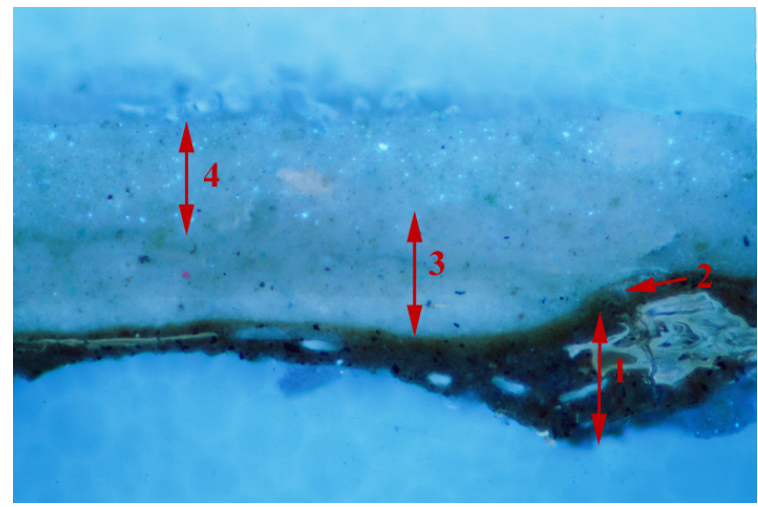

b)

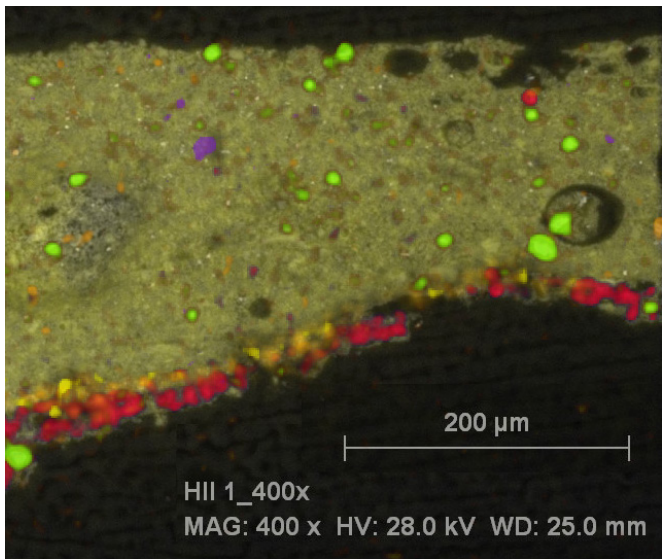

c)

il. 6. Przekrój z partii białej kulisy Salon Rokokowy, a) VIS, b) UV, c) SEM-EDS. Na skanie SEM-EDS zaznaczono: $\mathrm{Ca}$ (żółty transparentny), $\mathrm{Pb}$ (żółty ciepły), Cr(żółty cytrynowy), Fe (czerwień chłodna), Zn(fiolet), Ba (zieleń jasna). Fot. VIS W. Grzesik, UV-. Z. Rozłucka,; oprac. skanu SEM-EDS - E Szmit-Naud 


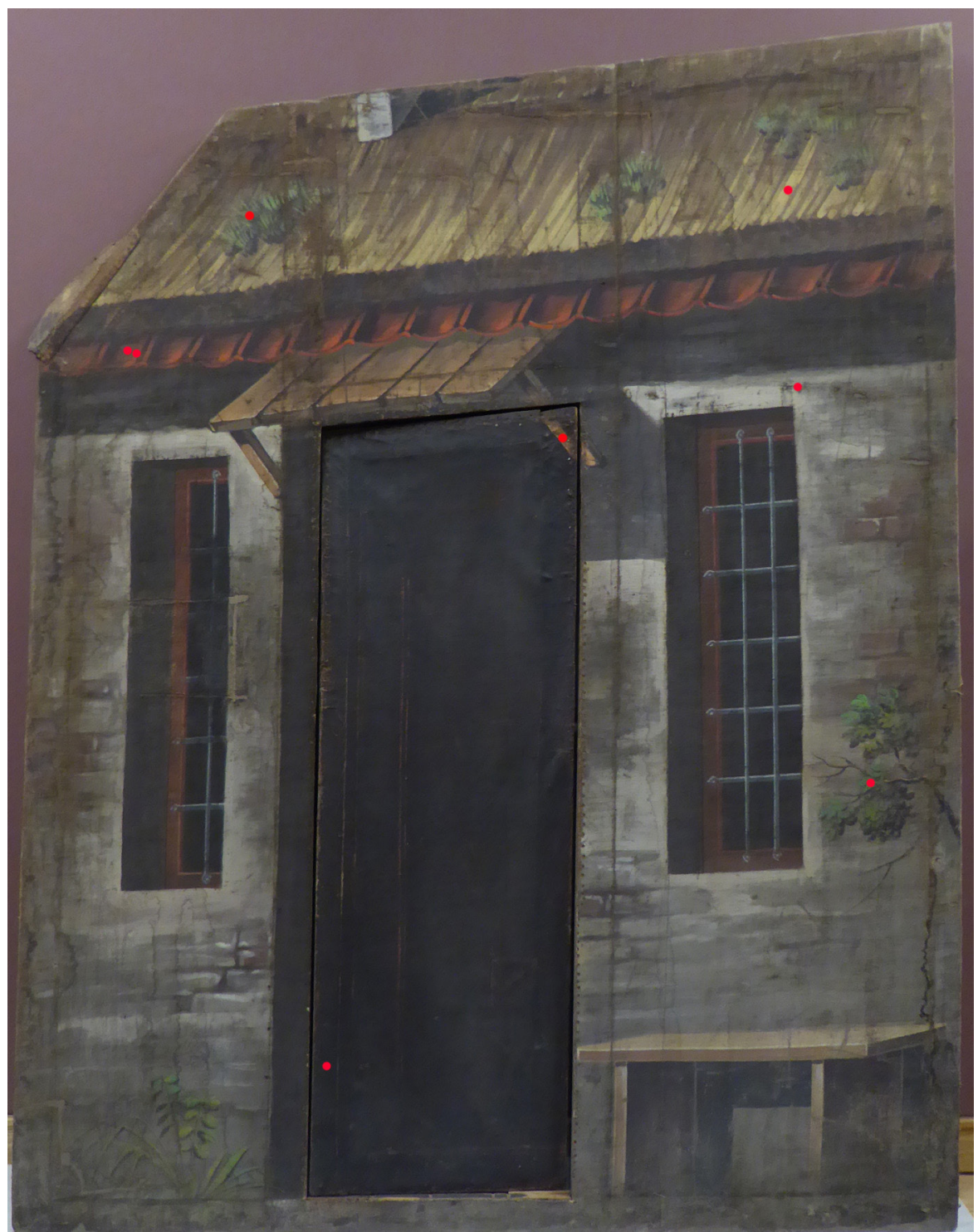

il. 7. Ferm Chata leśna. Zaznaczone miejsca poddane badaniom - z partii bieli (nad oknem), żółcieni (daszek, strzecha), czerwieni, brązu (dachówka), zieleni (kępka trawy, liście-krzak) i czerni (drzwi). Fot. E. Szmit-Naud 

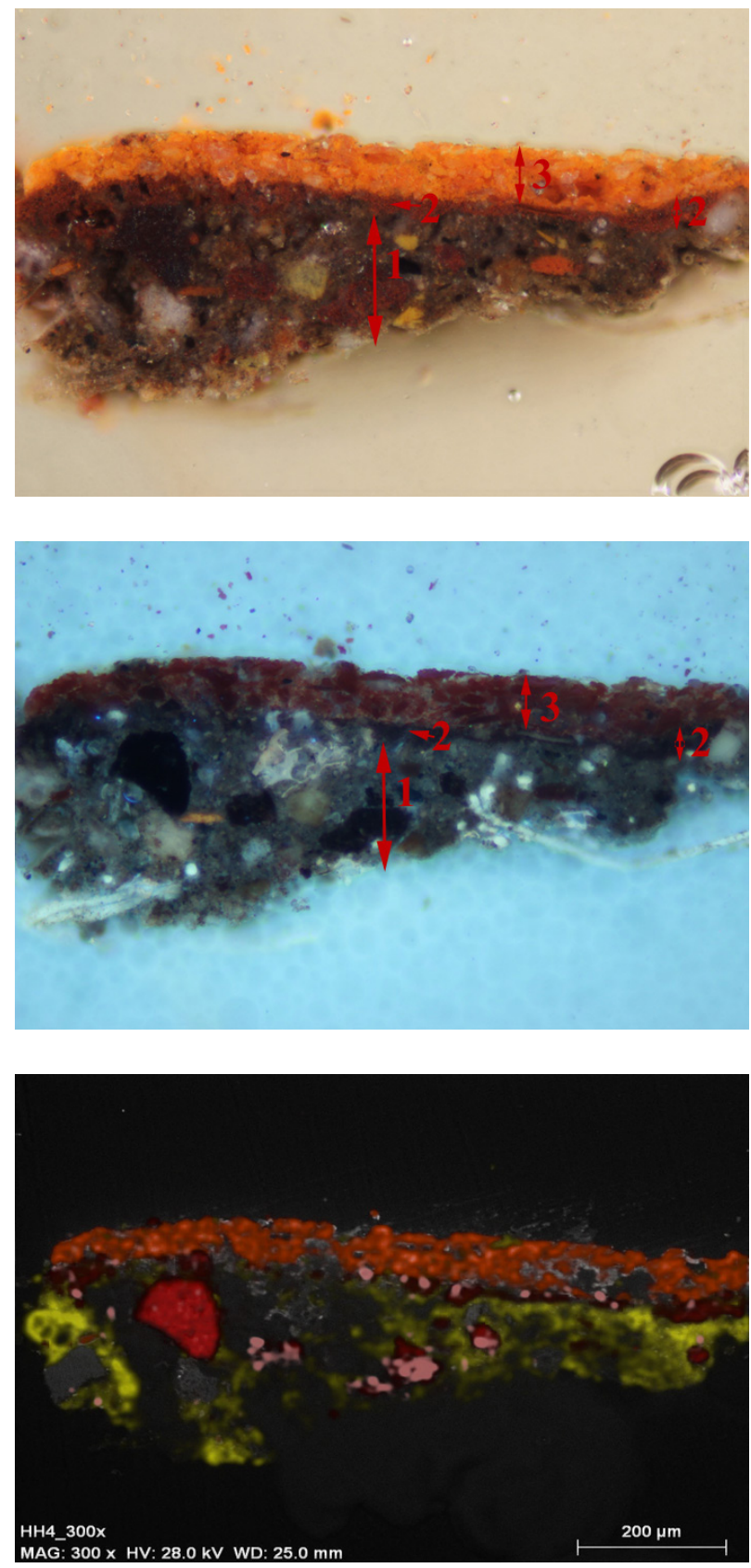

il. 8. Przekrój warstw fermu Chata Leśna - czerwona dachówka. a) VIS, b) UV, c) SEM-EDS. Na skanie SEM-EDS zaznaczono: Ca(żółty), Fe (czerwony), Ba (róż), Pb (oranż). Fot. VIS i UV - M. Iwanicka; oprac. skanu SEM-EDS - E Szmit-Naud 

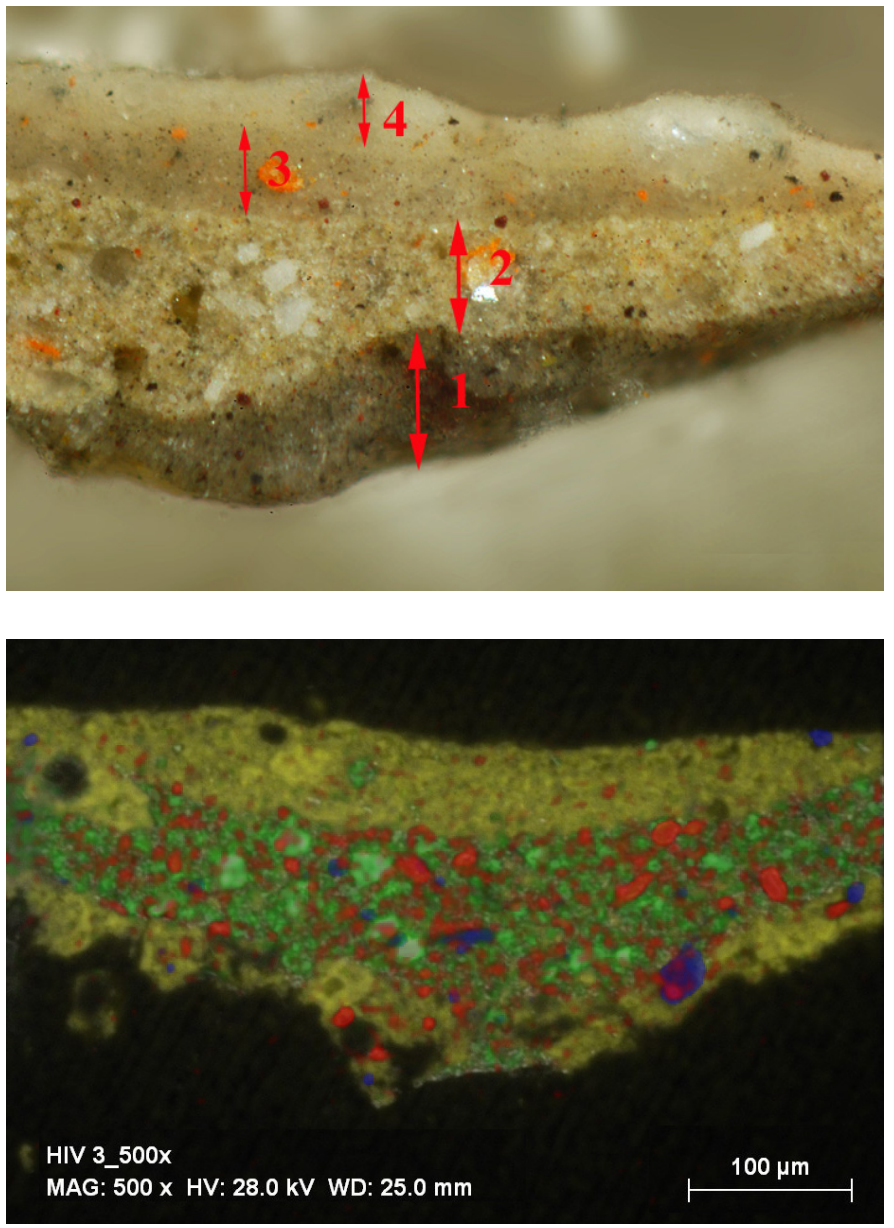

il. 9. Przekrój warstw fermu Chata Leśna - biel nad oknem. a) VIS, b) SEM-EDS. Na skanie SEM-EDS zaznaczono: Ca (jasny żółty), Fe (czerwony), $\mathrm{Pb}$ (zielony transparentny), Si (niebieski). Fot. VIS W. Grzesik; oprac. skanu SEM-EDS - E Szmit-Naud 

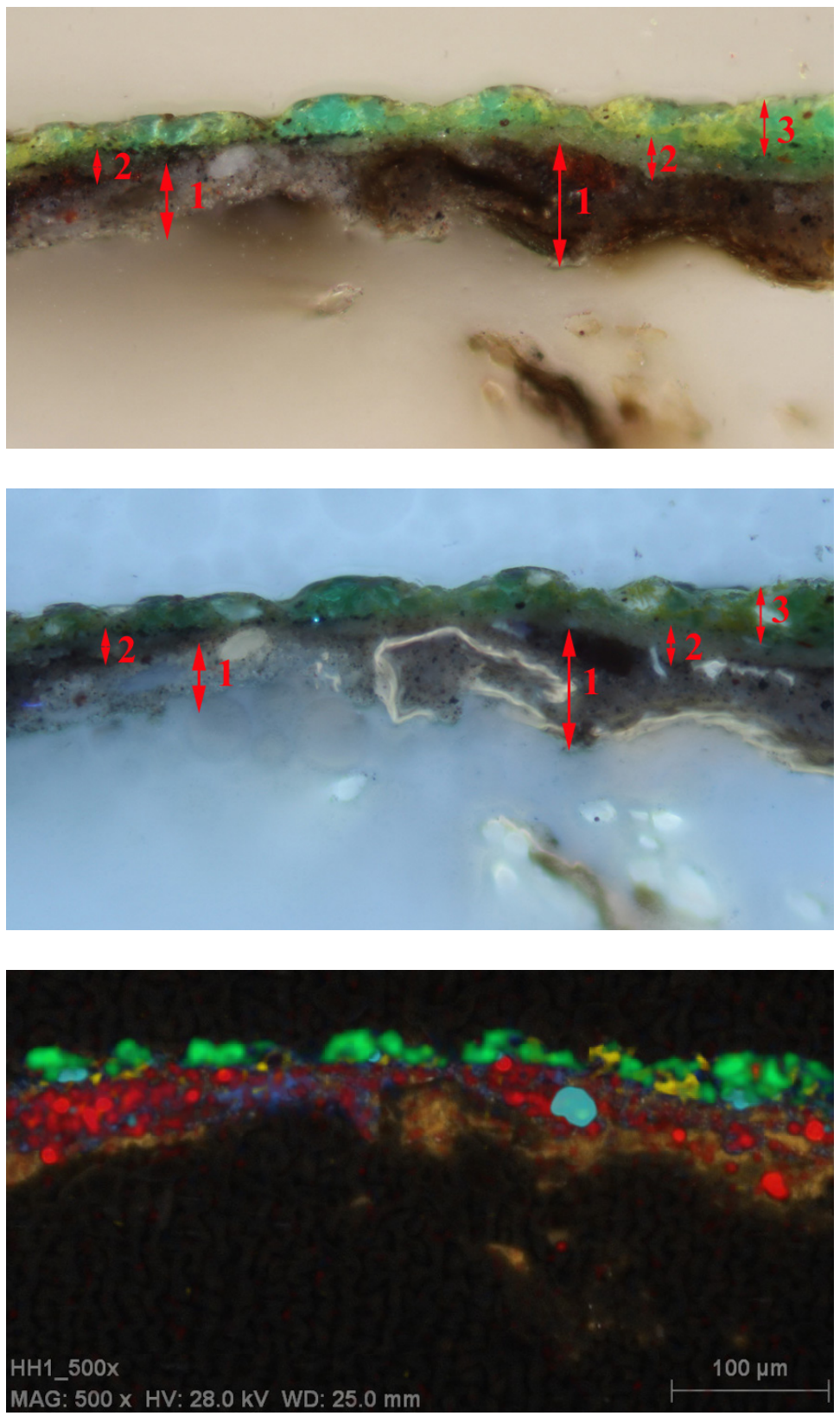

il. 10. Przekrój warstw fermu Chata Leśna - zieleń liść a) VIS, b) UV, c) SEM-EDS. Na skanie SEM-EDS zaznaczono: $\mathrm{Ca}$ (ugrowy), $\mathrm{Fe}$ (czerwony), $\mathrm{Pb} / \mathrm{As}$ (niebieski), $\mathrm{Cu}$ (zielony), $\mathrm{Cr}$ (żółty), Ba (błękitny). Fot. VIS i UV - M. Iwanicka; oprac. skanu SEM-EDS - E Szmit-Naud 


\section{Bibliografia}

Brænne, Jon. “Rapport Kunst og inventar nr 22/2005, Halden Teater Kulissesamlingen”. Raport fra befaringen den 6.6.2005, Oslo 2005, NIKU Oslo.

CAMEO Materials Database. “Chrome yellow”. Dostęp February 2, 2018, http://cameo. mfa.org/wiki/Chrome_yellow.

Coquiot, Gustave. Nouveau manuel complet de peintre décorateur de théâtre. Paris: Mulo, 1927 (faksymile z 1980 r.).

Courville de, Xavièr. Décors de théâtre: invention, construction, peinture, conseils d'un artisan aux amateurs. Paris: Editions Bourrelier, 1949.

Eastaugh, Nicholas, Valentine Walsh, Tracey Chaplin, i Ruth Siddal. Pigment Compendium. A Dictionary and Optical Microscopy of Historical Pigments. Amsterdam: Elsevier, Butterworth-Heinemann, 2008.

Meulen van der, Douwtje. „Mapping the Presence of Arsenic, Cooper and Lead on Wings and Backdrop of Theatre Scenery 'The woods'. Fredrikshalds Theatre”. IP project: 2013-1-NO1_ERA10-06367, Oslo 2013, University of Oslo.

Meulen van der, Douwtje. „Monumental Theatre Sceneries: Big Groups Big Problems?”. W Monumental Treasures Preservation and Conservation, red, Anna Rajainmoa, Marleena Vihakara, Satu Haapakoski, Stina Björklund, Erika, XX NFK Congress, 21-23 October 2015, Helsink: The Nordic Association of Conservators, Finish Section, 2015, 228-235.

Moynet, Georges. Trucs et décors, Explication raisonnée de tous les moyens employés pour produire les illusions théâtrales. Paris: Librairie illustrée,1893.

Parmer, Vidar. Fredrikshalds Teater 1838-1988. Halden: Halden Historiske Samlinger, 1988.

Parmer, Vidar. Teater, pantomime, linedans, ekvilibristikk, menasjeri, vokskabinett, kosmorama etc på Fredrikshald. Halden: Halden Komune, 1967.

Pérnety, Joseph-Antoine. Dictionnaire portatif de peinture, sculpture et gravure avec un traité pratique des différentes manières de peindre. Paris: Bauche, 1757. Dostęp february 10, 2018, https://archive.org/details/dictionnaireport00pern.

Polunin, Vladimir. The Continental Method of Scene Painting. London: Dance Books, 1980 (I wyd. 1927).

Szmit-Naud, Elżbieta. Europejskie zbiory iluzjonistycznych scenerii teatralnych - dziedzictwo docenione? Perspektywa konserwacji zapobiegawczej. Toruń: Wydawnictwo UMK, 2018.

Szmit-Naud, Elżbieta. „Iluzjonistyczne scenografie teatralne jako szczególny gatunek malarstwa dekoracyjnego. Technika wykonania na przykładzie dekoracji francuskich teatrów dworskich”. Acta Universitatis Nicolai Copernici. Zabytkoznawstwo i Konserwatorstwo 38, (2010): 143-167. 